Tepetaş Cengiz, G. Ş. ve Bal, M. (2020). Okul öncesi dönemde evde okuma süreci: Aile beklentilerine yönelik bir durum çalışması. Ana Dili Eğitimi Dergisi, 8(4), 1311-1331.

\begin{tabular}{c}
$\begin{array}{c}\text { Ana Dili Eğitimi Dergisi } \\
\text { Journal of Mother Tongue Education } \\
\text { www.anadiliegitimi.com }\end{array}$ \\
$\begin{array}{c}\text { Geliş/Received: } 28.08 .2020 \text { Kabul/Accepted: } 25.09 .2020 \\
\text { Araştırma Makalesi / Research Paper }\end{array}$ \\
\hline
\end{tabular}

\title{
Okul Öncesi Dönemde Evde Okuma Süreci: Aile Beklentilerine Yönelik Bir Durum Çalışması*
}

\author{
Gülüzar Şule TEPETAŞ CENGiz** \\ Mazhar $B A L^{* * *}$
}

Öz

Okumayı alışkanlık hâline getirmeyi sağlayan ve bunda rol oynayan birçok etken bulunmaktadır. Aile bireylerinin ve çevredeki bireylerin okumaya karşı istekli olmaları, örnek olmaları ve çocuk ile etkileşim kurmaları çocukların da olumlu olarak etkilenmelerini sağlayabilir. Okuma sürecinde önem verilen ve etkileşime girilen bu noktalar Okur Yanıt Teorisi'nin de temelini oluşturmaktadır. Bu çalışma ile okul öncesi dönemdeki çocukların evde aileleri ile gerçekleştirdikleri okuma süreçlerinin ailelerin beklentilerine göre Okur Yanıt Teorisi bağlamında incelenmesi amaçlanmaktadır. Nitel araştırma yöntemi ile gerçekleştirilen bu çalışma, durum incelemesi ile desenlenmiştir. Araştırmanın katılımcılarını, okul öncesi dönemde çocuğu bulunan 54 ebeveyn oluşturmaktadır. Veri toplama aracı olarak yarı yapılandırılmış görüşme formu kullanılmıştır. Çalışmada sonuç olarak ailelerin okuma süreçlerine iliş̧in beklentileri ile gerçekleştirdikleri etkinliklerdeki bakış açııının tutarlılık göstermediği belirlenmiştir. Ayrıca ailelerin beklentilerinin daha çok estetik bakış açısını yansıttığı sonucuna ulaşıımışır. Sadece okuma sonrası sürece ilişkin beklentilerde estetik amaçlı okuma ve bilgi için okuma bakış açısının öneminin aileler için eşit kabul edildiği tespit edilmiştir.

Anahtar Kelimeler: Okuma süreci, okuma bakış açısı, aile beklentileri, Okur Yanıt Teorisi

\begin{abstract}
Home Reading Process in Preschool Period: A Case Study on Family Expectations Abstract

There are many factors that make reading a habit and play a role in this. The willingness of the family members and the people around them to read, to set an example and to interact with the child also ensure that children are positively affected. These points that are emphasized and interacted with in the reading process also form the basis of the Reader Response Theory. In this study, it is aimed to examine the reading processes of preschool children with their families at home in the context of the Reader Response Theory according to the expectations of the families. This study, which was carried out with qualitative research method, was designed by case study. The participants of the study are 54 parents who have children in preschool period. Semistructured interview form was used as data collection tool. As a result of the study, it was determined that the expectations of the families regarding the reading processes and the point of view in the activities they performed were not consistent. In addition, it was concluded that the expectations of the families mostly reflected the aesthetic reading stance. It has been determined that the importance of aesthetic reading and efferent reading is regarded equally for families in the expectations regarding the post-reading process only.
\end{abstract}

Keywords: Reading process, reading stance, family expectations, Reader Response Theory

\footnotetext{
* Araştırmanın etik kurul izni: Bolu Abant İzzet Baysal Üniversitesi Sosyal Bilimlerde İnsan Araştırmaları Etik Kurulu, 26.06.2020, 2020/45.

** Dr. Öğr. Üyesi, Bolu Abant İzzet Baysal Üniversitesi, Mehmet Tanrıkulu Sağlık Hizmetleri Meslek Yüksekokulu, Çocuk Gelişimi Programı, Bolu, suletepetas@ibu.edu.tr, ORCID: 0000-0002-2034-9344.

*** Doç. Dr., Akdeniz Üniversitesi, Eğitim Fakültesi, Türkçe Eğitimi Ana Bilim Dalı, Antalya,

balmazhar@gmail.com, ORCID: 0000-0001-6958-9130.
} 


\section{Giriş}

Okul öncesi dönemde edinilen birçok alışanlık, davranış ve beceri yaşamın ileriki yıllarında sürdürülebilir. Bu dönemde becerilerin edinilmesinde, geliştirilmesinde ve sürdürülmesinde ailenin, yakın çevrenin, okulun ve öğretmenlerin önemli bir rolü bulunmaktadır (Kakırman Yıldız, 2016). Bu dönemde çocuğun yazılı materyaller ile buluşması, tanıması ve ilişkisi okuma alışkanlığının oluşmasında önemli bir başlangıçtır (Arıcı ve Tüfekci Akcan, 2019). Okumayı alışkanlık hâline getirmeyi sağlayan ve bunda rol oynayan birçok etken bulunmaktadır. Bunlar arasında aile, içinde yaşanılan toplum ve çevrenin özellikleri, okul, öğretmen, akranlar, sosyo kültürel özellikler, ekonomik durum sayılabilir (Duursma, 2014; Levy, Hall ve Preece, 2018; Raikes ve diğerleri, 2006; Gündüz, 2007). Bebeklik döneminden itibaren bireyin üzerinde en fazla etkisi olan aile faktörüdür (Tanju, 2010). Bu konuda Uluslararası Eğitim Başarılarını Değerlendirme Kuruluşu (IEA) ülkemizde 4. sınıf çocukları ile bir çalışma yapmıştır. Çalışmada çocukların okuma alışkanlıkları ve okumaya karşı ilgileri incelenmiştir. Anne ve babaların çocukların okuma becerisini geliştirme ve şekillendirmede önemli bir role sahip oldukları belirlenmiştir (aktaran: Sevim, 2003). Aile bireylerinin ve çevredeki bireylerin okumaya karşı istekli olmaları, örnek olmaları ve çocuk ile etkileşim kurmaları çocukların da bu süreçten olumlu olarak etkilenmelerini sağlamaktadır. Uluslararası okuma becerilerinde Gelişim Projesi'ne (PIRLS) göre Türkiye okuma alışkanlıkları konusunda 35 ülke arasında 28. sırada yer almıştır. 2001 yılında yapılmıs olan bu projenin verilerine göre Türkiye'deki bu başarısız sonucun en önemli sebebi ailelerin bebeklikten başlayarak okul öncesi dönem süresince çocukları ile birlikte yeterince okuma etkinliği yapmamaları gösterilmiştir (aktaran: Güner, Çelebi, Taşçı Kaya ve Korumaz, 2014). Bu da ailelerin çocukların okuma süreçlerinde önemli bir rolü olduğunu göstermektedir.

Ailelerin okumaya yönelik bakış açılarının yanı sıra okuma beklentilerinin de okul öncesi çocuklar üzerinde etkili olduğu düşünülmektedir. Aileler bu süreçte çocukların yaşlarına, gelişim özelliklerine, ilgilerine ve meraklarına, farklı temalara, kitapların fiziksel özelliklerine, dil ve içerik özelliklerine gibi birçok unsura dikkat ederek kitap seçimine katkı sağlamalıdır (Bamberger, 1990; Doyle ve Brambell, 2006; Işıkoğlu, Erdoğan, Şimşek ve Canbeldek, 2017; Sınar Çılgın, 2006). Bu yaş grubundaki çocuklar; farklı temalarda, konularda, resimlemelerde, boyutlarda, farklı yazarlar tarafından yazılmış kitaplar ile tanıştırılmalıdır. Tezel Şahin ve Tutkun (2016) okul öncesi dönemde çocuğu olan ailelerin genellikle çocuklarına kitap alırken en çok kitabın çocuğun yaşına uygun olmasına (resim yazı oranı), içeriğine (mesaj-tema-konu) ve kitabın yazarına dikkat ettiklerini belirlemişlerdir. Ailelerin en az dikkat ettikleri şeyin ise kitabın daha önce okunup okunmamış olması, çok satılması ve fiyatı olduğunu saptamışlardır. Çocuk Vakfı Raporu'na (2006) göre okul öncesi dönemde çocuk kitabı seçme işini genellikle annenin yaptığı bilinmektedir. Ayrıca Kıldan ve Gümrükçü Bilgisi (2011) de ülkemizde ailelerin en çok kitabın konusuna, mesajına ve içeriğine ilişkin bilgilere baktığını ve genellikle ebeveynlerin çocuk kitaplarının eğitici ders verici nitelikte olması gerektiğini savunduklarını belirlemişlerdir. Ailelerin genellikle çocuklarına öykü türünde resimli kitapları almayı tercih ettikleri de aynı çalışmada saptanmış önemli bir bulgudur. Benzer bir çalışma da Bayraktar ve Ersoy (2018) tarafından yapılmıştır. Çalışmalarında aileler en çok öykü türünde ve boyama türünde kitaplar aldıklarını belirtmişlerdir. Diğer kitap türlerini çok az aldıklarını, hatta çoğu zaman almadıklarını belirtmişlerdir. Aileler seçtikleri kitapları okurken de genellikle gece yatmadan önce okuduklarını ve kitabın yazılarını okuyarak resimlerini incelediklerini belirtmişlerdir.

Okuma sürecinde önem verilen ve etkileşime girilen bu noktalar Okur Yanıt Teorisi'nin de temelini oluşturmaktadır. Okuma, metindeki ipuçlarının seçimi, amaca yönelik seçici dikkat, okuma olayı sonrasında ve okuma işlemi boyunca okuyucunun uyarılmış cevapları, metnin estetik ve bilgi amaçlı okunması arasında sürekli devam eden amaç değişiminden oluşan karmaşık bir birleşimdir (Scherer, 2020). Rosenblatt (2005a) okuma sonrası çıkarılan anlamın okur ve metin arasında gerçekleşen dinamik bir etkileşim olduğunu söylemektedir. Rosenblatt $(1938,1978)$ metne bireysel yanıtlar geliştirilmesinin aktif ve anlamlı bir okumanın vazgeçilmez bir unsuru olduğunu belirtmektedir. Rosenblatt bu görüşleri ile okumanın bir süreç olduğunu belirten bir kuram ortaya koymuştur. Okuyucular Okur Yanıt Teorisine göre kişisel, dilsel ve deneyimsel birikimlerini hem özel hem sosyal ögeleri kullanarak, bazen bu ögeleri yeniden düzenleyerek ya da genişleterek metinleri anlamlandırırlar (Marhaeni, 1998). Bir öykü, metin, şiir ya da oyun bir okuyucu tarafından okunup etkileşim kurularak 
anlamlı semboller kümesine dönüştürülene kadar sadece kağıt üzerindeki mürekkep izleri olarak görülmektedir. Bu semboller kümesi bizler için bazı duyguları anında yaşama, bazı kişilerin özelliklerine bürünme, bazı durumlarda olaylara farklı bakabilme ve hayal gücüne katılarak yeniden düşüncelerimizi yapılandırabilmeyi sağlarlar. Bu da okunan metnin yalnızca bilgi vermesi değil aynı zamanda hayata katılarak da bilgi edindirmesini sağlar (Rosenblatt, 2005a).

Sipe (2008) Rosenblatt'ın Okur Yanıt Teorisi'nde okur ve metne aynı derecede önem verdiğini söylemektedir. Rosenblatt (1994) okurun durumunu okuma süreci içerisinde değişebileceğini belirterek iki farklı okumanın olduğundan bahsetmektedir:

1) Bilgi edinme amaçlı okuma: gazete, dergi okumak, elektronik aletlerin kullanım kılavuzlarını okumak, ilaçların prospektüslerini okumak bu tür okumaya örnek olabilir. Bilgi edinme amaçlı okumada metnin tüm bölümlerine bakılmaz sadece ilgi duyulan, merak edilen ya da ihtiyaç duyulan bölümler incelenir. Sözlükler ve ansiklopediler de bu şekilde okumaya örnektir. Bu okumada amaç bilgiye ulaşmaktır.

2) Estetik amaçlı okuma: bu okuma türünde bireyin zevk alması söz konusudur. Birey okumayı kendisi tercih eder, heyecan duyar ve tutku ile okuma eylemini sürdürür. Bazen kahramanların yerine kendini koyar, heyecanlanır, duygulanır, uyuyamaz ve kitabın sürükleyiciliğinden fizyolojik olarak da etkilenir. Kısacası, estetik okumada okunulan kaynağın birçok duyu ile hissedilmesi, kendiliğinden okumanın sürdürülmesi söz konusudur. Birey bilgi edinmek derdinde değildir. Ancak okuduklarından etkilenir ve o istemese de aklında kalıcı izler bırakır.

Okul öncesi dönemde olan çocukların estetik okumaya daha fazla yakın olduğunu belirten Rosenblatt (1994) bu okumanın bireyin yaşam boyu iyi bir okur olmasına öncülük ettiğini söylemektedir. Ancak çocukların kendilerini yaşama daha iyi hazırlamaları için bu iki okuma türünün de erken çocukluktan itibaren öğretilmesi gerektiğini belirtmektedir (Rosenblatt, 2005a). Okur Yanıt Teorisinde anlam, okuyucunun kişisel yanıtlarını deneyimleri ile birleştirmesi ile yapılanmaktadır (Flint, 2020). Oluşturulan anlam kişinin çevresi ile kurduğu etkileşim (iletişim, tartışma, konuşma) ile değişmektedir (Çakmak ve Yılmaz, 2009). Kişisel düşünceler ve deneyimler ışığında düzenlenen çocuğun düşünceleri akranlarının paylaştığı yeni bir fikirle, ailesinin gösterdiği yeni bir kaynakla, öğretmeninin paylaştığı yeni bir malzeme ile yenilenmektedir (Demeny, 2012). Rosenblatt Okur Yanıt Teorisinde bu durumu çocuğun yani okuyucunun bir metinle karşılıklı olarak diyalog kurması olarak açıklamaktadır. Çocuk ilk okumada ya da dinlemede bir metin ile karşılıklı olarak etkileşim kurmakta ve metindeki ipuçlarına yönelik olarak geçici bir çerçeve geliştirmektedir. Ardından çocuk ilerideki yanıtların seçimi ve sentezini etkileyecek bir metinsel beklenti oluşturur (Kaya ve Tosun, 2018). Çocuk metnin içinde etkilenmeye devam ettikçe bu beklenti bazen beklentileri ile başa çıkmaya ve mutluluğa bazen de kafa karışıklığına ve hayal kırıklığına sebep olur. Bazen çocuk beklentilerini yeniden gözden geçirir, düzenler bazen de yeni beklentiler geliştirir. Sonunda metinden bir anlam oluşturur (Flint ve Adams, 2018). Rosenblatt (2005a) çocuğun çıkardığı bu anlamın metnin kendisinin içinde olmadığını ve aksine anlamın metni okuyan her bireyde farklı biçimde oluştuğunu ortaya koymaktadır. Bireylerin çıkardıkları anlamların ve yanıtların birbirleri ile paylaşımının anlamlandırmada değişim oluşturarak yeni ve bambaşka anlamlar oluşturduğunu söylemektedir.

Alanyazında okul öncesi dönemde okuma süreçlerine ilişkin birçok çalışma bulunmaktadır. Bu çalışmaların çoğunlukla etkileşimli okuma, diyaloğa dayalı okuma, paylaşımlı okuma ile ilişkili olduğu belirlenmiştir. Çalışmaların birçoğunun okul öncesi öğretmenlerinin okuma süreçlerine yoğunlaştığı (Ergül, Akoğlu, Sarıca, Tufan ve Karaman, 2015; Hindman, Connor, Jewkes ve Morrison, 2008; Hutton ve diğerleri, 2017a, 2017b; Kotaman, 2008; Morrow ve Gambrell, 2005; Shahaeian ve diğerleri, 2018; Tercanlı Metin ve Gökçay, 2014; Whitehurst ve Lonigan, 1998) ancak ailelerinde çocukları ile birlikte yaptığı okuma süreçlerine yönelik çalışmaların olduğu (Aram ve Shapira, 2012; Bıçakçı, Er ve Aral, 2017; Demir-Lira, Applebaum, Goldin-Meadow ve Levine, 2018; Dixon-Krauss, Januszka ve Chae, 2010; Gonzalez, Taylor, Davis ve Kim, 2013; Hindman, Skibbe ve Foster, 2014; Işıkoğlu Erdoğan, 2016; Kim ve Anderson, 2008; Kotaman, 2007; Levy, Hall ve Preece, 2018; Marjanovič-Umek, Hacin ve Fekonja, 2017; Raikes ve diğerleri, 2006; Tipton, 2014; Vandermaas-Peeler, Sassine, Price ve Brilhart, 2011; Yurtseven, 2011)görülmektedir. Ancak okul öncesi dönemde ailelerin çocuklarının okuma süreçlerine ilişkin beklentilerinin belirlenmesine yönelik herhangi bir çalışmaya rastlanılmamıştır. Bu bağlamda 
okul öncesi dönemdeki çocukların evde aileleri ile birlikte gerçekleştirdikleri okuma süreçlerinden ailelerinin beklentilerinin belirlenmesinin amaçlandığı bu çalışmanın gerek Türkiye'deki alanyazına gerekse uluslararası alanyazına önemli katkılar getireceği düşünülmektedir. Türkiye'deki alanyazın incelendiğinde Okur Yanıt Teorisi'nin kullanıldığı okul öncesi alanında çalışmalarında yok denecek kadar az olduğu belirlenmiştir (Dedeoğlu ve Kardaş, 2013; Dedeoğlu ve Ulusoy, 2013; Dedeoğlu, Ulusoy ve Alıcı, 2013). Bu nedenle bu çalışmanın gerek Okur Yanıt Teorisi'nin okul öncesi alanında uygulanması gerekse ailelerin çocukların okuma süreçlerinden beklentilerinin ortaya konması bağlamında önemli bir çalışma olduğu söylenebilir.

Bu çalışma ile okul öncesi dönemdeki çocukların evde aileleri ile gerçekleştirdikleri okuma süreçlerinin ailelerin beklentilerine göre Okur Yanıt Teorisi bağlamında incelenmesi amaçlanmaktadır. Evde gerçekleştirilen okuma süreçleri sırasında ailenin öğrencileri için seçtiği kitap tercihleri Okur Yanıt Teorisi açısından değerlendirilmiştir. Bu amaçla da aşağıdaki sorulara cevap aranmıştır:

1. Evde gerçekleştirilen okuma süreçlerinde aileler, çocukları için seçtiği kitaplarda nelere dikkat etmektedir?

2. Evde gerçekleştirilen okuma süreçlerinde ailelerin seçtiği kitaplar hangi bakış açısını yansıtmaktadır?

3. Evde gerçekleştirilen okuma süreçlerinde ailelerin kitaba yönelik sorduğu sorular hangi bakış açısını yansıtmaktadır?

\section{Araştırmanın Modeli}

\section{Yöntem}

Nitel araştırma yöntemi ile gerçekleştirilen bu çalışma, durum incelemesi ile desenlenmiştir. Belli bir durumu, bütüncül bir bakış açısıyla ele alan bir desen olması, (Creswell, 2009; Glesne, 2013; Merriam, 2013) bu araştırma için durum incelemesinin seçilmesinin ana sebebini oluşturmaktadır. Çünkü bu araştırmada okul öncesi dönemdeki çocukların evde aileleri ile gerçekleştirdikleri okuma süreçleri, ailelerin bakış açısına dayandırılarak incelenmiştir. Özellikle okul öncesi dönemdeki çocukların evde okuma süreçlerinde ailelerin beklentileri bütüncül bir bakış açısıyla ortaya koyulmaya çalışılmıştır. Okul öncesi dönemdeki çocukların aileleriyle gerçekleştirilen bu çalışmada bütüncül tekli durum deseni kullanılmıştır. Bütüncül tekli durum deseni, genellikle alanyazında az ele alınmış ve bir kuramın teyit edilmesi veya çürütülmesi amacıyla kullanılan bir desen olmuştur (Yin, 2009). Bu çalışmada bütüncül tekli durum deseninin tercih edilmesinin sebebi ise çocukların okuma sürecine ilişkin ailelerin beklentilerinin okuma eğitimi açısından çerçeve niteliği taşıyan ve Louise Rosenblatt tarafından geliştirilen Okur Yanıt Teorisine dayandırılarak incelenmesidir. Özellikle Türkiye'de yapılan çalışmalara bakıldığında daha önce okul öncesi dönem çocuklarının okuma süreçlerinde aile beklentilerinin Okur Yanıt Teorisi'ne dayandırılarak incelenmemesi de bütüncül tekli durum deseninin seçilmesinin bir diğer sebebini oluşturmaktadır.

\section{Araştırma grubu}

Araştırmanın katııımcılarını, Türkiye'nin kuzey batısında yer alan şehirlerden birinden seçilen okul öncesi dönemdeki çocukların aileleri oluşturmaktadır. Bütün araştırmalarda olduğu gibi nitel araştırmada da her açıdan ekonomiklik önem taşımaktadır. Bu açıdan kolay ulaşılabilir durum örneklemesi hem zaman hem de ekonomiklik açısından araştırma sürecine katkıda bulunur (Patton, 2014). Araştırmanın katılımcılarına dair bilgiler Tablo 1 'de yer almaktadır.

Tablo 1.

Katılıma bilgileri

\begin{tabular}{lc}
\hline Meslek & Katılımcı Sayısı \\
\hline Öğretmen & 23 \\
Ev hanımı & 5 \\
Kamuda memur & 5 \\
Akademisyen & 3
\end{tabular}




\begin{tabular}{ll} 
Kuran kursu öğreticisi & 2 \\
Fizyoterapist & 2 \\
Hemşire & 2 \\
İşçi & 1 \\
Hâkim & 1 \\
Bankacı & 1 \\
Doktor & 1 \\
Uçak teknisyeni & 1 \\
Bilgisayar Teknikeri & 1 \\
Bankacı & 1 \\
Öğrenci & 1 \\
Arabulucu Avukat & 1 \\
Din Görevlisi & 1 \\
İşletmeci & 1 \\
Özel Sektör Ofis Çalışanı & 1 \\
\hline
\end{tabular}

Tablo 1'de görüldüğü üzere araştırmanın katılımcıları 54 (8 erkek, 46 kadın) kişiden oluşmaktadır. Ailelerin yaşları 21 ile 48 yaş arasında değişmektedir. Değiş̧ik meslek gruplarından oluşan bu katılımcıların çoğunun okul öncesi dönemde sadece 1 çocuğu olduğu görülmektedir. Araştırmanın bulgular bölümünde katılımcılardan alıntılar yapılırken gerçek isimleri yerine "K1, K2, K3,..., K54" takma isimleri kullanılmıştır. Bu kısaltmada yer alan "K" harfi "katılımcı" kelimesinin kısaltılmış hâli olup sayılar ise Tablo 1'de yer alan sıraya göre verilmiştir.

\section{Veri Toplama Araçları}

Nitel araştırma yöntemi ile desenlenen bu çalışmada yine nitel araştırma tekniklerinden biri olan yarı yapılandırılmış görüşme formu kullanılmıştır. Okul öncesi dönemdeki çocukların aileleriyle gerçekleştirilen çalışmada, iki farklı yarı yapılandırılmış görüşme formu geliştirilmiş̧ir. Bu görüşme formlarına ve geliştirilme süreçlerine ilişkin bilgiler şu şekildedir:

\section{Ailelerin okuma sürecine ilişsin beklentilerinin belirlenmesine yönelik yarı yapılandırılmış görüşme formu}

Bu yarı yapılandırılmış görüşme formu, araştırma sürecinde ailelerin okuma sürecinden çocuklarıyla ilgili ne beklediklerini belirlemek için geliştirilmiştir. Sorular oluşturulurken araştırmanın amacına odaklanılmıştır (Merriam, 2013). Araştırmanın amacından hareketle okul öncesi dönemdeki çocukların ailelerinin okuma sürecine ilişkin beklentilerini belirlemek için 6 soru geliştirilmiştir. Sorular geliştirilirken okuma sürecinin aşamaları dikkate alınmıştır. Geliştirilen bu soruların kapsam geçerliğini denetlemek amacıyla uzman görüşleri alınmıştır (Glesne, 2013). Uzmanlardan gelen dönütler doğrultusunda soru sayısı eksilmemiş ya da azalmamıştır. Sadece soruların okuma süreçleri açısından daha net ifadeler hâline getirilmesine yönelik dönütlerde bulunulmuştur. Bu dönütler doğrultusunda sorular yeniden düzenlenmiş ve pilot uygulama yapılmıştır. Araştırmanın katılımcıları dışında farklı ailelerle yapılan pilot uygulama sonunda görüşme formunun anlaşılırlığı denetlenmiştir. 6 sorudan oluşan yarı yapılandırımış görüşme formu, okuma sürecine yönelik ailelerin beklentilerini bütüncül olarak belirlemeye hizmet etmektedir. Formun içeriğine bakıldığında üç alt bileşenden oluştuğu söylenebilir. Okuma öncesi, okuma süreci ve okuma sonrası olarak belirlenen bu bileşenlerin her birinde öncelikle ailenin bu aşamalardan neler bekledikleri ardından ise bu aşamalarda neler yaptıkları sorulmuştur.

\section{Okul öncesi dönemdeki çocuklarına evde okumak için seçtikleri kitaplara ilişkin ailelerin bakış açısının belirlenmesine yönelik yarı yapılandırıımış görüşme formu}

Bu yarı yapılandırılmış görüşme formu, okul öncesi dönemdeki çocuklara aileleri tarafından seçilen kitaplara yönelik ailelerin bakış açısını belirlemektir. Yukarıda açıklanan yarı yapılandırılmış görüşme formunda olduğu gibi bu form için de sorular araştırmanın amacıyla ilişkili olarak 
hazırlanmıştır (Merriam, 2013). Araştırmanın amacından hareketle okul öncesi dönemdeki çocukların ailelerinin kitaplara yönelik bakış açısını belirlemek için 7 soru geliştirilmiştir. Geliştirilen bu sorular, kapsam geçerliği açısından denetlenmek amacıyla uzman görüşüne sunulmuştur (Glesne, 2013). Uzmanlardan gelen dönütler doğrultusunda soru sayısı aynı kalmışıı; fakat soruların amaca daha çok hizmet edebilmesi için dönütlerde bulunulmuştur. Bu dönütler doğrultusunda sorular yeniden düzenlenmiş ve pilot uygulama yapılmıştır. Araştırmanın katılımcıları dışında farkıı ailelerle yapılan pilot uygulama sonunda görüşme formunun anlaşılırlığı denetlenmiştir. 7 sorudan oluşan yarı yapılandırılmış görüşme formu, kitaplara yönelik ailelerin bakış açısını bütüncül olarak belirlemeyi amaçlamaktadır. Yarı yapılandırılmış görüşme formunun içeriğine bakıldığında soruların kitabın özelliklerine, kitap seçme ölçütlerine, çocuk ve yetişkin kitapları arasındaki farklar ve benzerliklere, kitapla ilgili sorulan soruların amacına yönelik olduğu görülmektedir.

\section{Verilerin Analizi}

Çalışmanın verileri, araştırma sorularına hizmet edecek şekilde düzenlenmiştir. Her bir araştırma sorusuyla ilgili veriler farklı şekilde analiz edilmiştir. Araştırma soruları bağlamında veri analiz süreci şu şekilde açıklanabilir:

\section{Birinci araştırma sorusuna yönelik veri analizi}

$\mathrm{Bu}$ araştırma sorusuna yönelik ailelerle yapılan görüşme verileri, içerik analizi tekniği ile çözümlenmiştir. Verilerin analizinde dört kategori altında toplam 47 koda ulaşılmıştır. Bu araştırma sorusunun içerik analizine ilişkin detaylı bilgilere bulgular bölümünde yer alan Tablo 2'de yer verilmiştir. Analiz sonuçları giriş bölümünde detaylı olarak açıklanan Okur Yanıt Teorisine dayandırılarak yorumlanmıştır.

\section{ikinci araştırma sorusuna yönelik veri analizi}

$\mathrm{Bu}$ araştırma sorusuna yönelik elde edilen veriler, içerik analizi tekniği ile çözümlenmiştir. Verilerin analizinde toplam 75 kod elde edilmiştir. Bu kodlardan hareketle de 6 farklı kategoriye ulaşıımıştır. Bu araştırma sorusunun içerik analizine ilişkin detaylı bilgiler bulgular bölümünde yer alan Tablo 3'te sunulmuştur. Analiz sonuçları giriş bölümünde detaylı olarak açıklanan Okur Yanıt Teorisi'ne dayandırılarak yorumlanmıştır.

\section{Üçüncü araştırma sorusuna yönelik veri analizi}

Bu araştırma sorusuna yönelik veriler, betimsel analiz tekniği ile çözümlenmiştir. Betimsel analiz teması olarak Wollman-Bonilla ve Werchadlo (1995) tarafından geliştirilen kategoriler temel alınmıştır. Wollman-Bonilla ve Werchadlo (1995) çalışmasında okuma sürecinde çocukların tepkilerini metin merkezli tepkiler (yeniden anlatma, karakterleri anlama, soru sorma, tahmin etme) ve okur merkezli (kişisel tepkiler, yaşamla ilişkilendirme, anlatılana katılma isteği) tepkiler olarak ikiye ayırmıştır. Wollman-Bonilla ve Werchadlo tarafından geliştirilen bu sınıflama iki ana başık altında, yedi alt başlıktan oluşmaktadır. Bu başlıkların tamamı üçüncü araştırma sorusunun verileri analiz edilirken tema olarak kullanılmıştır. Fakat bu başlıklara ek olarak ailelerin görüşlerinden hareketle metin merkezli bakış açısında dört farklı temaya daha ulaşıımıştır. Soruları doğru cevaplama, olayı anlama, ana fikir ve resimleri açıklama isimli bu temalara ve Wollman-Bonilla ve Werchadlo tarafından geliştirilen temalara göre gerçekleştirilen betimsel analiz sonuçları bulgular bölümündeki Tablo 4'te yer almaktadır.

Yapılan görüşmelerde, katılımcılar çalışmanın amacı hakkında önceden bilgilendirilmiş ve katılımcılara bilgilendirilmiş gönüllü onam formu imzalatılmıştır. Çalışma süreci boyunca araştırma ve yayın etiğine uyulmuştur.

Araştırmanın güvenirliği için okul öncesi ve Türkçe eğitimi alanında uzman iki araştırmacı tarafından veriler ayrı ayrı kodlanmıştır. Yapılan kodlamalar karşılaştırılıp farklılıklar konusunda uzlaşılmıştır. Böylece iki uzman arasındaki kodlama güvenirliği (Miles ve Huberman, 1994: 64) \%90 olarak tespit edilmiştir. Araştırmanın geçerliğini arttırmak için veri toplama araçları ve bu araçların geliştirilme aşamaları hakkında detaylı bilgiler sunulmuştur. Katıımcılarla yapılan görüşmelerden elde 
edilen veriler, analiz edilmiş ve analiz kodları doğrudan alıntılarla desteklenmiştir. Böylece araştırmanın onaylanabilirliği arttırılmaya çalışılmıştır.

\section{Etik Kurulu İzni}

Kurul adı = Bolu Abant İzzet Baysal Üniversitesi Sosyal Bilimlerde İnsan Araştırmaları Etik Kurulu Karar tarihi $=26.06 .2020$

Belge sayı numarası $=2020 / 45$

\section{Bulgular}

Araştırmanın bu bölümünde verilerden hareketle elde edilen bulgular sunulmuş ve yorumlanmıştır. Bulgular, araştırma sorularındaki sıralama takip edilerek raporlanmıştır. Bu açıdan ilk olarak evde gerçekleştirilen okuma süreçlerinde ailelerin çocukları için seçtikleri kitaplarda nelere dikkat ettiklerine ilişkin bulgular yorumlanmıştır. Tablo 2'de ailelerle yapılan görüşmelerde kitap seçerken nelere dikkat ettiklerine ilişkin elde edilen verilerin içerik analizine yer verilmiştir.

Tablo 2.

Ailelerin Çocukları İçin Seçtikleri Kitaplarda Neleri Dikkate Aldıkları

\begin{tabular}{|c|c|c|c|}
\hline Tema & Kategori & Kod & $f$ \\
\hline \multirow[t]{34}{*}{ Kitap seçimi } & Çocuklara kitap seçme ölçütleri & İlgi çekicilik & 15 \\
\hline & & Zengin görsel içerik & 13 \\
\hline & & Yayınevi & 10 \\
\hline & & Eğiticilik & 5 \\
\hline & & Hayal dünyasını zenginleştirme & 4 \\
\hline & & Yazar & 4 \\
\hline & & Olumsuzluk içermeme & 3 \\
\hline & & Anlaşılırlık & 2 \\
\hline & & Yazı ve resim uyumu & 2 \\
\hline & & Yakın tavsiyesi & 2 \\
\hline & & Konu & 2 \\
\hline & & Çok satılanlar listesi & 1 \\
\hline & & Günlük yaşama aktarılabilirlik & 1 \\
\hline & Çocuk kitabının özellikleri & Zengin görsel içerik & 15 \\
\hline & & Anlaşılırlık & 9 \\
\hline & & İlgi çekici & 8 \\
\hline & & Eğiticilik & 8 \\
\hline & & Düzeye uygunluk & 6 \\
\hline & & Olumlu yönlendirme & 3 \\
\hline & & Olumsuzluk içermeme & 2 \\
\hline & & Akıcılık & 2 \\
\hline & & Hayal dünyasını zenginleştirme & 1 \\
\hline & & Sosyal mesajdan uzak & 1 \\
\hline & & Yazı ve resim uyumu & 1 \\
\hline & Yetişkin ve çocuk kitabı & Yok & 27 \\
\hline & arasındaki benzerlik & Hitap etme & 4 \\
\hline & & Din ve ahlak & 4 \\
\hline & & Sürükleyicilik & 2 \\
\hline & & Yayınevi ve yazar & 1 \\
\hline & & Bilgiye dayalı olması & 1 \\
\hline & & Sağlıklı beslenme konusu & 1 \\
\hline & & Eğiticilik & 1 \\
\hline & & İçerik & 1 \\
\hline & & Anlaşılırlık & 1 \\
\hline
\end{tabular}




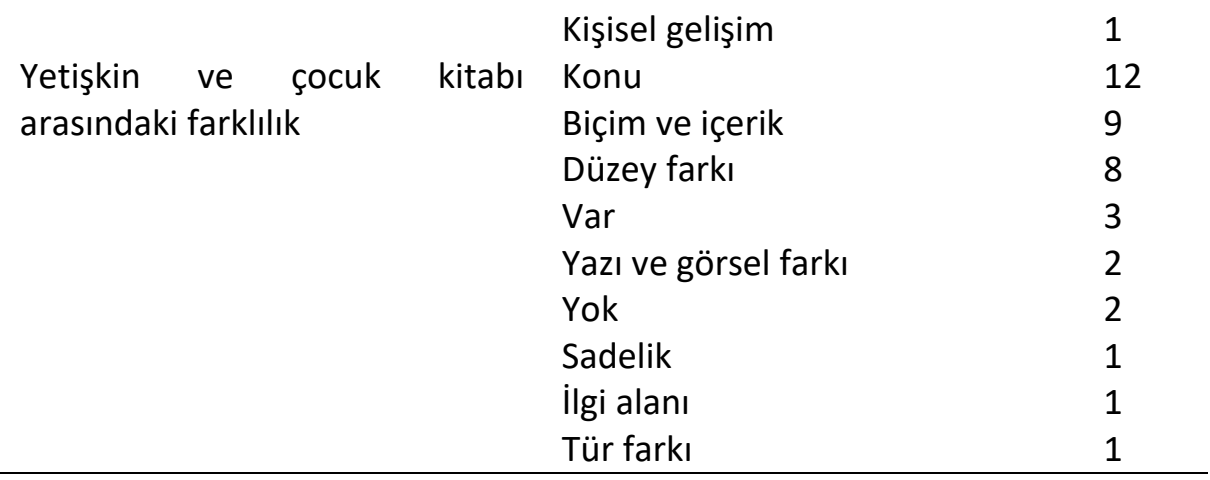

Tablo 2'de görüldüğü üzere ailelerin evde gerçekleştirilen okuma süreçlerinde çocuklarına kitap seçerken neleri dikkate aldıklarına ilişkin sorulara verdikleri cevapların analizi kitap seçimi teması altında toplanmıştır. Sıklık değeri açısından sırasıyla "çocuklara kitap seçme ölçütleri $(f=64)$, çocuk kitabının özellikleri $(f=56)$, yetişkin ve çocuk kitabı arasındaki benzerlik $(f=44)$, yetişkin ve çocuk kitabı arasındaki farklılık ( $\mathrm{f}=39$ )" kategorileri altında toplam 203 koda ulaşıımıştır.

Sıklık değeri en yüksek olan "çocuklara kitap seçme ölçütleri" adlı kategori Tablo 2'de yer almaktadır. Bu kategori 14 koddan oluşmaktadır. Okur Yanıt Teorisi açısından bakıldığında bu kategoriye ait "zengin görsel içerik, yayınevi, eğiticilik, yazar, olumsuzluk içermeme, anlaşılırlık, yazı ve resim uyumu, yakın tavsiyesi, konu, çok satılanlar listesi, günlük yaşama aktarılabilirlik" adlı kodların bilgi için okuma bakış açısını yansıttığı görülmektedir.

Bilgi için okuma bakış açısını yansıtan bu kodlardan "zengin görsel içerik ile yazı ve resim uyumu" adlı kodlara ilişkin örnek ifadeler şu şekilde gösterilebilir:

"Bol resimli kitaplar tercih ediyorum." (K3).

"Az sayfalı çok resimli yazısı büyük kitaplar seçiyorum." (K7).

"Kitapların içeriğinde çocuğun hoşuna gidecek görsellerin olması ilk tercihimdir." (K22).

"Çizimlerinde konuya uygunluğuna bakarım." (K43).

"içeriğindeki görsellerle konunun uyuşup uyuşmadığına bakıyorum." (K45).

Yukarıdaki örnek ifadelerden de anlaşılacağı üzere aileler çocuklarına kitap seçerken görsel içerikle ilişkili olarak bilgi için okuma bakış açısını tercih etmektedir.

"Eğiticilik, olumsuzluk içermeme, anlaşılırlık ve konu" kodları ise aşağıdaki örnek ifadelerde görüleceği üzere bilgi için okuma bakış açısının farklı bir boyutunu yansıtmaktadır.

"Resim ve yazılarının net, anlaşılır olması yeterli."(K42).

"Kitap seçerken kriterim kitabın olumsuz herhangi bir içerik taşımaması. Örneğin okula başlangıç aşamasında okula gitmek istemeyen bir çocuğun hikâyesini okumaktansa hikâyenin içerisinde okula gitmeyi seven bir çocuğun anlatılmasını tercih ederim." (K3).

"Ben hikâyesine kısa bir göz atıyorum tuhaf davranış aşılamaları ve çocuğun aklını karıştıracak uygunsuz içerikler olabiliyor çünkü." (K32).

"Bu çok çok önemli bir konu mesela bizim çocuğumuzun kitabı olan kırmızı başlıklı kız masalında kurdun karnını kesme, dikme olayı bir çocuk için idrak etmesi gereken zor bir kavram oluyor oraları maalesef atlayarak okuyorum." (K36).

"Davranış ve değerler eğitimi kapsamında olmalı." (K18).

"Ahlaki katkısı olmasına önem veriyorum." (K49).

"Konusuna göre seçim yapıyorum." (K34).

Örnek ifadelerden de anlaşılacağı üzere aileler bilgi için bakış açısını yansıtan ifadelere yer vermişlerdir. Bu bakış açısını ise çocukları için seçmiş oldukları kitapların içeriğiyle ilişkilendirmişlerdir. Yine içerikle ilişkili olarak aileler, "yayınevi, yazar, yakın tavsiyesi ve çok satılanlar listesi" kodlarıyla da bilgi için okuma bakış açısını yansıtmaktadır.

Çünkü bu kodların adından da anlaşılacağı üzere aileler, içeriğin güvenirliğine ve herkesçe kabul edilebilirliğine önem verdiklerini göstermektedir. Bu açıdan da Tablo 2'de yer alan "çocuklara kitap seçme ölçütleri" kategorisi altında ailelerin görüşlerinden elde edilen kodların sıklık değerinin \%70'i bilgi için okumaya yönelik bakış açısını yansıtmaktadır. \%30'u ise estetik okuma bakış açısını 
yansıtmaktadır. Estetik okuma bakış açısını yansıtan kodlar ise "ilgi çekicilik ve hayal dünyasını zenginleştirme" dir. İlgi çekicilik kodu, sıklık değeri en tez olan koddur. Bu koda yönelik aile görüşleri aşağıdaki örnek ifadelerde görüldüğü şekildedir:

"Dikkatini çekecek ve yaşına uygun konular olmasına..." (K30).

"ilgi alanına göre kitap seçiyorum." (K47).

"Kızımın sevdiği, ilgilendiği alanlarda olmasına dikkat ediyorum." (K49).

"Konusu ve çizimleri çok önemli benim için bir de kızımın ilgi ve karakterine uygun seçimler yapmaya çalışıyorum." (K19).

"Kitapları çoğu zaman beraber seçiyoruz. Yaşına, seviyesine, ilgisine uygun mu kontrol ediyoruz." (K23).

"Yaş ve çocuğumun ilgi kriterine göre seçiyorum." (K29).

Yukarıdaki örnek cümlelerden hareketle ailelerin çocuklarının ilgi ve ihtiyaçlarını dikkate alarak kitap seçimlerini yaptıkları söylenebilir. Bu açıdan bakıldığında aileler, çocuklarının duygularını kitap seçiminde önemli bir ölçüt olarak görerek estetik okuma bakış açısını yansıtmaktadır. Estetik okuma bakış açısına yönelik bir diğer kodda da çocukların hayal dünyası ön plana çıkarılarak şu ifadelere yer verilmiştir:

"Hayal gücünü zenginleştiren kitaplar seçiyoruz." (K1).

"Iyi resmedilmiş olmalı, hayal gücünü kullanabileceği nitelikte olması." (K6).

"Hayal dünyasına hitap edebilecek görsel ve işitsel zenginliği olmalı." (K13).

"Hayal gücünü destekleyici olmasını seviyorum." (K26).

Yukarıdaki ifadeler, çocuklarının hayal dünyasını zenginleştirici içeriğe sahip kitapların aileler tarafından tercih edildiğini göstermektedir. Bu ölçüt, onların doğrudan estetik okumaya yönelik bakış açısını yansıtmaktadır. "Çocuk kitabı özellikleri" adlı kategoride de benzer dağıım dikkat çekmektedir. Tablo 2'de görüldüğü üzere bu kategori toplam 11 ayrı koddan oluşmaktadır. Bu kodların sıklık değerinin toplamının \%82'si bilgi için okuma bakış açısını yansıtmaktadır. Bu bakış açısını yansıtan kodlar şu şekildedir: "Zengin görsel içerik, anlaşılırlık, eğiticilik, düzeye uygunluk, olumlu yönlendirme, olumsuz yönlendirme, akıcııı, yazı ve resim uyumu". Bilgi için okuma bakış açısının bu kodlarla ilişkili katılımcı görüşlerine şu şekilde örnekler verilebilir:

"Bol resimli ve az metin içeren kitaplar tercih ediyorum. Mümkünse üç boyutlu ve karton kapak arkasına resim yerleştirilen kitapları daha çok tercih ediyorum. Çünkü bu tür kitaplar çocukta merak uyandırıyor ve daha uzun süre dikkatini verebiliyor." (K3).

"Yazıları büyük puntolu olmalı, sade bir dille yazılması, içeriğindeki karakterleri konuşturabilecek şekilde konuşma çizgileri olması." (K6).

"Çocuklara verdiği değer teması tarafsız olmalı her bireyde olması gereken genel Ahlak değerlerinin dışına çıkmamalı." (K33).

"Dini ve ahlaki erdemleri daha küçüklükten itibaren dimağlara nakşetmeli." (K49).

"Anlaşılır, akıcı, keyifli olmalı, sevgiyi, merhameti, iyiliği öğretmeli, çocuğu hüzünlendirmemeli." (K50).

"Kötü ya da olumsuz kelimeler davranışlar olmamalı." (K11).

"Çocuğun yaşına uygun uzunlukta olmalı." (K19).

Yukarıdaki örnek ifadelerden anlaşılacağı üzere aileler, bir kitabın özelliklerini sıralarken içerisindeki bilgiye, bilginin nasıl sunulduğuna ve bilginin çocuk tarafından kitapta verildiği şekilde anlaşıımasına odaklanmaktadır. Kitap özelliği olarak bu ölçütler, onların bilgi için okuma bakış açısının yansımasıdır. Tablo 2'de yer alan "çocuk kitabı özellikleri” kategorisinin "ilgi çekicilik, hayal dünyasını zenginleştirme, sosyal mesajdan uzaklık" adlı diğer kodlarına bakıldığında bu kodların da estetik okuma bakış açısının yansıması olan görüşlere sahip olduğu düşünülmektedir. Bu görüşler, ilgili kategorinin sıklık değerinin \%18'ini oluşturmaktadır. Bilgi için okuma bakış açısına göre yüzde açısından oldukça düşük olan estetik okuma bakış açısı, ailelerin görüşlerine şu şekilde yansımıştır:

"Kitabın kapağı çocukların ilgisini çekmeli, akıcı olmalı ve çocuğu kendine bağlamalı." (K47).

"Çocukların hem hayal dünyasını geliştiren hem de birlikte bir çıkarımda bulunabildiğimiz kitapları seviyorum." (K41). 
"illa bir sosyal mesaj içermemeli yani tek amaç bu olmamalı. İyilerin kazandığı kurtların tilkilerin kötü olduğu masallar olmamalı." (K9).

Bu örnek ifadelerden anlaşılacağı üzere ailelerin bazıları için önemli olan, kitapların çocuğun duygu dünyasına hitap etmesi, hayal gücünü geliştirmesi ve belli kalıplara sıkıştırmamasıdır. Çocukların duygu dünyalarına hitap etmek, ailelere göre bir kitapta bulunması gereken önemli bir özellik olarak kabul edilmektedir. Bununla birlikte ailelere, çocuk ve yetişkin kitapları arasındaki benzerlikler ve farklı yönler sorulduğunda farklı bulgulara ulaşılımıştır. Tablo 2 'de görüldüğü üzere bu konuda görüş belirten ailelerin çoğu benzerlik olmadığını $(f=27)$ ifade etmiştir. Benzerlik olduğunu belirten ailelerin görüşleri ise ( $f=17)$ Tablo 3'te görüldüğü üzere 10 farklı kodla sınıflandırılmıştır. "Hitap etme, din ve ahlak, sürükleyicilik, yayınevi ve yazar, bilgiye dayalı olması, sağlıklı beslenme konusu, eğiticilik, içerik" kodlarından oluşan bu görüşlerde dikkat çeken nokta ise ailelerin benzerlik olarak ifade ettikleri noktaların estetik okuma bakış açısından uzak olmasıdır. Sadece "hitap etme" kodunun estetik okuma bakış açısıyla ilgili olabileceği, görüşlere şu şekilde yansımıştır:

"ilgimizi çekebilen kitaplar olmaları olabilir." (K5).

"Tabi ki ilgimize göre." (K35).

"ilgi alanı." (K39).

Görüşlerden anlaşılacağı üzere bazı katılımcılar, estetik okuma bakış açısını yansıtan bu ifadelere yer vermiştir. Ifadelere bakıldığında estetik okuma bakış açısının öne çıktığı görülmektedir; fakat dikkat çeken bir başka bulgu ise ailelerin çocuklarıyla ilgi alanlarını aynı görmeleridir. Bu bakış açısı Tablo 2'de yer alan farklılıklar kategorisinde de dikkat çekmektedir. Bu kategori içerisinde de aileler farkııık olarak hep bilgi amaçlı okuma bakış açısını yansıtan algıya yönelik görüşlerini sunmuştur. Sadece K7 numaralı katılımcı estetik okuma bakışa açısıyla ilgili şu görüşe yer vermiştir: "ilgi alanımız farklı olduğu için ilgi alanlarımıza uygun kitap seçmeye özen gösteriyorum." (K7). Bunun dışında K1, K3 ve K20 numaralı katılımcılar da hiçbir gerekçe sunmadan sadece farklılık var ifadesini kullanmıştır. Diğer katıımcılar ise tamamen bilgi amaçlı okumayı merkeze alan bir bakış açısıyla farklılıkların ne olduğunu ifade etmiştir.

Çalışmanın ikinci araştırma sorusuyla evde gerçekleştirilen okuma süreçlerinde ailelerin çocukları için seçtikleri kitaplardaki bakış açısı belirlenmeye çalışılmıştır. Tablo 3'te ailelerin bakış açısını belirlemeye yönelik yapılan görüşmelerin içerik analizi sonucu sunulmuştur.

Tablo 3.

Ailelerin Çocukları İçin Seçtikleri Kitaplardaki Bakış Açısı

\begin{tabular}{|c|c|c|c|}
\hline Tema & Kategori & Kod & $f$ \\
\hline Okumaya yönelik bakış & Okuma öncesi beklenti & ílgili olma & 19 \\
\hline \multirow[t]{16}{*}{ açısı } & & Dikkat & 11 \\
\hline & & Hayal gücünü geliştirme & 5 \\
\hline & & Eğlenme & 3 \\
\hline & & Kitaba yönelik fikir üretme & 2 \\
\hline & & Anlama & 2 \\
\hline & & $\begin{array}{ll}\text { Kelime } & \text { bilgisinin } \\
\text { zenginleşmesi } & \end{array}$ & 2 \\
\hline & & Davranış eğitimi & 1 \\
\hline & & Okuma alışkanlığı & 1 \\
\hline & & $\begin{array}{l}\text { Kitabı ve okumayı } \\
\text { önemseyen }\end{array}$ & 1 \\
\hline & & Dinlemeye hazır olma & 1 \\
\hline & & Görsellerle ilgilenmesi & 1 \\
\hline & Okuma öncesi etkinlik & İçerik & 19 \\
\hline & & Resimler & 14 \\
\hline & & Karakterler & 3 \\
\hline & & Önbilgi sunma & 2 \\
\hline & & Hiçbir şey & 1 \\
\hline
\end{tabular}


Okuma sürecinde beklenti

Okuma sürecinde etkinlik

Okuma sonrası beklenti

Okuma sonrası etkinlik
Kitap okumanın önemi 1

Tür 1

Etkin dinleme 1

Dikkat 13

Kitaba yönelik soru sorması 9

İlgili olma 7

Anlama 7

Yorumlama 3

Resimleri yorumlaması 3

Eğlenme 2

Pasif dinleyici 1

Hayal gücünü geliştirme 1

Duygusal dengeyi koruması 1

Soruları cevaplama $\quad 1$

Sabırlı olma 1

Karakterler 12

Soru-cevap 9

Resimler 7

Davranış değerlendirme 4

İçerik 3

Yeni kelimeler kazandırma 3

Anlaşılırlığı sağlama 1

Değerlendirme 1

Detaylar 1

Hayal gücünü zenginleştirme 1

Tekrar ettirme 1

Hiçbir şey 1

Olay 1

Ana fikir 1

Anlama 6

Anlatma 6

Eğlenme 5

Yaşamına aktarma 5

İçeriği hatırlama 4

Yorumlama 4

Kitabı sevme 3

Soruları cevaplama 3

Mutlu olması 3

Kitaba yönelik soru sorması 2

Kelime hazinesinin 2

zenginleşmesi

Doğru davranış kazanma 1

Okuma alışkanlığı kazanma 1

Hayal gücünü geliştirme 1

Ders çıkarma 1

Okuma isteği 1

Resimleri yorumlaması 1

Soru-cevap 11

Ana fikir 8

İçerik 6

Davranış değerlendirme 4

Olay 4 


$\begin{array}{ll}\text { Karakterler } & 3 \\ \text { Değerlendirme } & 3 \\ \text { Hitap etmiş olma } & 2 \\ \text { Tekrar ettirme } & 2 \\ \text { Resimlere bakarak tekrar } & 1 \\ \text { anlatma } & \\ \text { Özet } & 1\end{array}$

Tablo 3'ten de anlaşılacağı üzere okuma süreciyle ilgili ailelerin beklentilerine yönelik verilerin analizinde 75 farklı koda ulaşılmıştır. Bu kodlar, altı kategori altında toplanmıştır. Bu kategoriler sırasıyla "okuma öncesi beklenti ( $f=49)$, okuma öncesi etkinlik ( $f=42)$, okuma sürecinde beklenti $(f=49)$, okuma sürecinde etkinlik ( $f=46)$, okuma sonrası beklenti ( $f=49)$, okuma sonrası etkinlik $(f=45)^{\prime \prime}$ şeklindedir. Bu kategorilerin tamamından hareketle ise "okumaya yönelik bakış açısı" temasına ulaşıımıştır.

Tablo 3’te de görüleceği üzere okuma öncesi beklentilere bakıldığında “ilgili olma, hayal gücünü geliştirme, eğlenme, kitaba yönelik fikir üretme, okuma alışkanlığı, kitabı ve okumayı önemseyen" kodları aileler tarafından estetik okuma bakış açısının önemsendiğini göstermektedir. Aşağıdaki örnek ifadeler ailelerin bu bakış açısını somutlaştırmaktadır:

"Kitaptaki görseller üzerine konuşurken kendi fikrini söylemesi, yorum yapması...." (K6).

"Kitabın adına, resimlerine bakarak fikir yürütmesi..." (K10).

"Kitabı okurken eğlenmesi ve kitap okuma alışkanlığı kazanabilmesine katkı..." (K5).

"Hayal dünyasının çeşitlenmesi ve sakinleşmesi..." (K13).

"Kitap okumaya geçmeden önce istekli olması kendisinin kitabını alıp gelmesi en büyük mutluluk ve beklentim." (K15).

"isteyerek heyecanla eline alması, her an kitap okumak ya da okutmak için an gözetmesi." (K20).

Örnek ifadelerden de anlaşılacağı üzere okuma sürecine geçmeden önce aileler, çocuklarından yorumlayarak yeni anlamlar oluşturmasını, kitabı ve genel olarak kitap okumayı sevmesini, hayal dünyasının zenginleşmesini beklemektedir. Bu beklenti onların estetik okuma bakış açısını benimsediklerinin göstergesidir. Bu bakış açısı, okuma öncesi beklentilere yönelik görüşlerin \%63'ünü oluşturmaktadır. Geri kalan \%37'si ise bilgi amaçıı okuma bakış açısını yansıtan beklentilerdir. Okuma öncesi beklentilere yönelik bu bulgularla ilişkili olarak okuma öncesi etkinlikler için Tablo 3'e bakıldığında "içerik, resimler, karakterler, önbilgi sunma, hiçbir şey, kitap okumanın önemi, tür, etkin dinleme" adlı toplam 8 koda ulaşıldığı görülmektedir. Bu kodların \%95'i bilgi amaçlı okuma bakış açısıyla etkinliklerin gerçekleştirildiğini göstermektedir. Sadece K35'in şu ifadeleri ile kısmen estetik okuma bakış açısını yansıtan etkinlikler gerçekleştirdiği söylenebilir: "Kitap okumanın faydalarını...". Asında K35 tarafından sunulan bu görüş de sadece kitap okuma alışkanlığına ve kitap okumayı sevmeye atıfta bulunduğu için estetik okuma bakış açısı olarak değerlendirilebilir.

Okuma sürecinde aile beklentilerine ilişkin bulgulara bakıldığında Tablo 3’te görüldüğü üzere "kitaba yönelik soru sorma, ilgili olma, yorumlama, resimleri yorumlama, eğlenme, hayal gücünü geliştirme, duygusal dengeyi koruma" kodlarından hareketle estetik okuma bakış açısının katıımcıların beklentilerini yönlendirdiği söylenebilir. Estetik okuma bakış açısı okuma sürecinde ailelerin beklentilerine şu şekilde yansımıştır:

"Sabırla resimlere bakıp, kendi hikâyesini oluşturmasını istiyorum. Bu sayede aslında aklındakileri duygularını aktarmış oluyor bana." (K31).

"Karakterin yaptığı şeyi sorunca yorumlamasını istiyorum ya da taklit etmesini." (K30).

"Sorular sorması, merak etmesi, hayal gücünü kullanması." (K6).

"Kitap okurken aktif olması yani katılması bir şeyler söylemesi tekrar etmesi ya da sorması mutlu ediyor beni bir anne olarak. Hem keyif aldığını görüyorum hem de meraklı olduğunu öğrendiğini veya öğrenmeye çalıştığını görüyorum." (K15).

Yukarıdaki örnek cümlelerden de anlaşılacağı üzere ailelerin çoğu okuma sürecinde çocuklarının duyguları ve hayal dünyalarıyla hareket etmelerini, metni yeniden yorumlamalarını 
beklemektedir. Estetik okuma bakış açısını yansıtan bu beklentiler, okuma sürecine yönelik görüşlerin $\% 55$ 'ini oluşturmaktadır. Okuma sürecindeki beklentilerin \%45'inin ise bilgi için okuma bakış açısını yansıttığı söylenebilir. Okuma sürecindeki beklentilerin aksine okuma sürecinde gerçekleştirilen etkinlikler, Tablo 3'te görüldüğü üzere \%85 düzeyinde bilgi amaçlı okuma bakış açısına hizmet etmektedir. Okuma sürecinde gerçekleştirilen etkinliklere yönelik görüşlerin $\% 15^{\prime} i$ ise estetik okuma bakış açısını yansıtmaktadır.

Tablo 3'e bakıldığında okuma sürecinin son aşaması olan okuma sonrası sürece ilişkin aile beklentilerine ilişkin kodların sıklık değerleri arasında daha homojen bir dağılım dikkat çekmektedir. Bu homojen dağıım bilgi için okuma ve estetik okuma bakış açısının dağılımında da kendini göstermektedir. Ailelerin okuma sonrası sürece ilişkin beklentilerinin $\% 50$ 'si bilgi amaçlı okuma; \%50'si de estetik okuma bakış açısını yansıtmaktadır. Okuma sonrası etkinliklerde ise bu eşit dağııı durumu değişmektedir. Okuma sonrası etkinliklere yönelik görüşlerin \%80'i etkinliklerin bilgi için okuma bakış açısına hizmet ettiğini gösterirken \%20'si estetik amaçlı okuma bakış açısına hizmet ettiğini göstermektedir.

Çalışmanın son araştırma sorusuyla evde gerçekleştirilen okuma süreçlerinde ailelerin çocukları için seçtikleri kitaplara ilişkin sorduğu soruların yansıttığı bakış açısı belirlenmeye çalışıımıştır. Bu bakış açısını belirlemeye yönelik katılımcılarla yapılan görüşmelerin içerik analizi Tablo 4'te yer almaktadır.

Tablo 4.

Ailelerin Çocukları Iç̧in Seçtikleri Kitaplara iliş̧kin Sorduğu Soruların Yansıttığı Bakış Açısı

\begin{tabular}{lll}
\hline Odak & Etkinlik & $f$ \\
\hline Metin & Olayı anlama & 19 \\
& Karakterleri anlama & 9 \\
& Ana fikir & 5 \\
& Hikâyeyi yeniden anlatma & 4 \\
& Tahmin etme & 3 \\
& Soru sorma & 2 \\
& Resimleri açılama & 2 \\
Okur & Kişisel tepki (düşünceler ve hisler) & 25 \\
& Hikâye ile deneyimleri arasında bağlantı kurma & 3 \\
& Hikâyedeki olaylara katılma isteği & 1 \\
\hline
\end{tabular}

Ailelerin çocukları için seçtikleri kitaplara ilişkin sorduğu soruların hangi bakış açısını yansıttığı ile ilgili görüşlerin analizinin yer aldığı Tablo 4'te görüldüğü üzere sorular iki tema altında sınıflandırımıştır. Bunlar metin merkezli $(f=44)$ ve okur merkezli $(f=29)$ şeklindedir. Soruların analizi sonucunda metin merkezli sorularla ilgili sıklık değeri açısından en çok dikkat çeken "olayı anlama" etkinliğidir. Bu etkinliğe yönelik sorular şu şekilde örneklendirilebilir:

"Kitaptaki olaylarla ilgili sorular soruyorum anlayıp anlamadığını görmek için." (K2).

"Dikkatinin dağılmaması için sorular sorarım aynı zamanda hikâyeye ilgili sorarım ki anlayıp anlamadığını, kendini kitaba verip veremediğini ölçebileyim, diye." (K41).

"Anlayıp anlamadığını, dikkat edilmesi gereken noktayı kavrayabilmiş mi kısmını amaçlıyorum." (K12).

"Kitabın içeriğine yönelik açık uçlu sorular sormaya çalışırım." (K42).

"Kitabın içerisindeki anlatılmak istenen olayı anlamasını amaçlıyorum." (K28).

Yukarıdaki ifadelerden de anlaşılacağı üzere aileler, metin merkezli etkinliklerde en fazla olayı anlama ile ilgili sorular sormaktadır. Bu soruların amaçlarını ise anlama boyutunu belirleme, içeriğin kavranması olduğunu belirtmişlerdir. Tablo 4'te Wollman-Bonilla ve Werchadlo'nun (1995) soru analiz temaları dışında "resimleri açıklama" adı altında farklı bir etkinlik daha göze çarpmaktadır. Bu etkinlikle ilgili ailelerin görüşleri şu şekildedir:

"Kitabın içeriği hakkında sorular soruyorum. Özellikle resimlerde neler gördüğünü soruyorum." (K37). 
"Söylediğim cümlenin tekrarı ve görselde gördüğü şeyleri anlayıp onlar hakkında konuşması." (K22).

K37 ve K22'ye ait olan bu görüşlerden anlaşılacağı üzere çocukların resimleri görüp anlaması, onlar hakkında görüşlerini sunması katılımcıların soru sorma amaçlarının temelini oluşturmaktadır. Okur merkezli sorulara bakıldığında Tablo 4'ten anlaşılacağı üzere en fazla kişisel tepkileri belirlemeye yönelik sorular sorulduğu görülmektedir. Bu sorular ve amaçları katılımcıların görüşlerine aşağıdaki örnek ifadelerde görüldüğü şekilde yansımıştır:

"Okuduğumuz kitaptaki karakterlerin yerine kendimizi koyup ne yapardık sorusunu sıkça soruyorum." (K8).

"Gerçekten ilgilendiğini ve sevip sevmediğini tespit etmeyi amaçlıyorum." (K50).

"Onun duygularını, karakterini anlamaya çalışıyorum. Ayrıca bazen cevapları daha önce söylemediği kırgınlıkları ya da sevinçlerini ortaya çıkarabiliyor." (K31).

"Ona göre doğru yanlış kavramlarının oturup oturmadığı, kendi olsaydı neler yapardı, nasıl hissederdi, ruh halini nasıl düzeltebileceği, kendini kötü durumda nasıl iyi hissedebileceği, hayatta karşılaşacağı zorlukların, güzelliklerin iyi ve kötü insanların olacağını ve bunun nasıl üstesinden geleceğini..." (K25).

"Kitap okurken iyi bir dinleyici olmasını, kendini karakterlerin yerine koyarak o olsaydı ne yapardı bunları amaçlıyorum." (K7).

"Hayal dünyası beni en çok etkileyen şeydir. Merak uyandırmış mi, keyif almış mı bunlara bakıyorum." (K10).

Örnek ifadelerde görüldüğü üzere aileler, en çok çocuklarının duygularını ve kişisel tepkilerini merak etmektedir. Okur merkezli sorularıyla da merak ettikleri bu konularla ilgili çocuklarının görüşlerini belirlemeye çalışmaktadırlar. Ayrıca çocuklarının empati becerilerini geliştirmeye çalışarak duygu dünyalarına katkıda bulunmak için de katılımcıların sorular sorduğu dikkat çekmektedir.

\section{Tartışma ve Sonuç}

$\mathrm{Bu}$ araştırma, okul öncesi dönemdeki çocukların evde aileleri ile gerçekleştirdikleri okuma süreçlerinin ailelerin beklentilerine göre incelenmesi amacıyla gerçekleştirilmiştir. Evde gerçekleştirilen okuma süreçleri sırasında ailelerin çocukları için seçtiği kitaplar, okuma süreci beklentileri, okuma etkinlikleri ve soru sorma amaçları Okur Yanıt Teorisi açısından değerlendirilmiştir. Okul öncesi dönemde ailelerin çocuklarının okuma süreçlerine ilişkin beklentilerinin belirlenmesine yönelik alanyazında herhangi bir çalışmaya rastlanmamıştır. Türkiye'deki alanyazın incelendiğinde Okur Yanıt Teorisi'nin kullanıldığı okul öncesi alanında çalışmaların (Dedeoğlu ve Kardaş, 2013; Dedeoğlu ve Ulusoy, 2013; Dedeoğlu, Ulusoy ve Alıcl, 2013) da yok denecek kadar az olduğu belirlenmiştir. Bu nedenle bu çalışmanın gerek Okur Yanıt Teorisi'nin okul öncesi alanda uygulanması gerekse ailelerin okuma süreçlerine ilişkin beklentilerinin belirlenmesi açısından alanyazındaki diğer çalışmalardan farklı bir amaca hizmet ettiği düşünülmektedir.

Okuma sürecine yönelik bulgulara genel olarak bakıldığında ailelerin okuma öncesi beklentilerinin çoğunun estetik amaçlı okuma bakış açısına yönelik olduğu söylenebilir. Bu beklenti okuma sürecinde daha da düşerek bilgi için okumayla yakınlaşmıştır. Okur Yanıt Teorisi açısından bakıldığında okuma sürecinde bilgi için okuma ve estetik okuma bakış açısının dengesinin önemli olduğu söylenebilir. Wuryaningrum, Suyitno, Suyono ve Sunaryo (2017) çalışmasında öğrencilerin estetik bakış açısı sayesinde bilgi için okuma bakış açısını sağlayabildiği ve benzer şekilde bilgi için okuma bakış açısının da estetik okuma bakış açısını temsil edebildiği sonucuna ulaşmıştır. Onlara göre bu iki bakış açısı, birbirinin tamamlayıcısıdır. Ailelerin okuma sürecine ilişkin çocuklarından beklentilerine ilişkin bulgular incelendiğinde de ailelerin okuma öncesi beklentileri arasında estetik okuma bakış açısının önemsendiğine ilişkin bazı kodların yer aldığı görülmektedir. Ailelerin çocukların eğlenmesini önemsedikleri bu kodlar arasında yer almaktadır. Özdemir (2000) çocukların ileriki yaşlarda okuma motivasyonuna sahip olması için erken yaşlarda eğlendirici ve düşündürücü ögeler içeren kitaplar okumaları gerektiğini söylemektedir. Sever (2003) de çocukların okuma alışkanlığı edinebilmeleri için yalnızca bilgi veren kitaplar ile karşılaştırılmaması gerektiğini, eğlendirici kitapların da aileler tarafından tercih edilmesi gerektiğini vurgulamıştır. Sanacore (2006) da çocukların kitapların 
eğlendirici bir yönünün olduğunun farkına varmasının onların yaşam boyu iyi birer okuyucu olmaları açısından önemli olduğunu çalışmasında ortaya koymuştur.

Ailelerin çocukları için kitap seçerken nelere dikkat ettiklerine ilişkin bulgulardan hareketle en çok dikkat çeken ölçütün çocukların ilgilerine hitap etmek, olduğu belirlenmiştir. Sadece bu ölçütle bakıldığında ailelerin estetik okuma bakış açısını merkeze aldıkları söylenebilir; fakat katııımcıların tamamı dikkate alındığında çoğunluğun bilgi için okuma bakış açısını merkeze alarak kitap seçtiği görülmektedir. Bu açıdan bakıldığında ailelerin kitap seçerken estetik okuma bakış açısından çok bilgi için okuma bakış açısına önem verdikleri sonucuna ulaşılmıştır. Çocuk kitaplarında bulunması gereken özelliklerle ilgili bulgularda ise bilgi için okuma bakış açısının daha çok öne çıktığı belirlenmiştir. Hatta çocuk kitabı seçerken dikkat edilen ölçütlerle ilgili bulgularla karşılaştırıldığında ailelerin çocuk kitaplarında bulunması gereken özelliklerde estetik okuma bakış açısına daha az önem verdikleri görülmektedir. Bu açıdan ailelerin bir kitapta bulunması gereken özellikleri bilgi merkezli ele aldıkları sonucuna ulaşımıştır. Estetik okuma ve çocuğun duygu dünyasını harekete geçirecek özellikte kitapların ise onlar için öneminin ikinci sırada yer aldığı söylenebilir. Yetişkin ve çocuk kitapları arasındaki benzerlik ve farklılıklara yönelik bulgulara bakıldığında bilgi amaçlı okuma bakış açısının aileler için önemli olduğu sonucuna ulaşılmıştır. Ailelere göre çocuk kitapları ve yetişkin kitaplarının ortak noktası kitabın içeriği, içeriğin güvenirliği, bir şeyler öğretebilmesidir. Bu da doğrudan aileler tarafından bilginin merkeze alındığını göstermektedir. Daha genel ifadeyle aileler, kendilerine kitap alırken bilgi amaçlı okuma bakış açısını merkeze almaktadır. Aynı zamanda bu bakış açısı, çocuklarına seçtikleri kitaplarla kendilerine seçtikleri kitapların da ortak noktasını oluşturmaktadır. Çocuk kitapları ile yetişkin kitapları arasındaki farklılıklara yönelik bulgularda da aynı durum söz konusudur. Sadece bir katılımcı, çocuğun ilgi ve ihtiyaçlarının yetişkinlerden farklı olacağına, bu yüzden de kitapların farklılaşacağına yönelik görüş bildirmiştir. Araştırmanın bulgularından anlaşılacağı üzere ailelerin çocuk kitabı seçerken sergiledikleri bakış açısı daha çok bilgi amaçlı okuma bakış açısını yansıtmaktadır. Kıldan ve Gümrükçü Bilgici (2011) ile Öztürk Samur ve Çiftçi'nin (2019) çalışması da araştırmanın bulgularını desteklemektedir. Kıldan ve Gümrükçü Bilgici (2011) çalışmalarında okul öncesi eğitim alan çocuklar için ailelerin kitap seçme ölçütlerini incelemişlerdir. Onlara göre aileler resimli öykü kitabı seçerken kitabın eğiticilik ve olumsuzluk içermemesine dikkat etmektedir. Ailelerin \%85'i hikâye kitaplarının seçiminde eğiticiliği önemsediğini belirtmiştir. Yine Öztürk Samur ve Çiftçi'de (2019) ailelerin nitelikli çocuk kitabı seçebilme yetkinliklerini inceledikleri çalışmalarında ailelerin genellikle çocuklar için seçtikleri kitapların eğitici bir yönü olması gerektiğini belirttiklerini saptamışlardır. Okul öncesi döneme ait masalları ve hikâyeleri inceledikleri çalışmalarında Cengiz ve Duran (2017) ise bu araştırmanın bulgularından çok farklı sonuçlara ulaşmıştır. Cengiz ve Duran (2017) okul öncesi dönem çocukları için ailelerin masal ve hikâyeleri tercih etme gerekçelerini sorgulamışlardır. Çalışmalarında ailelerin okumaya başlamadan önce eseri belirlerken resim ve yazı uyumuna yani estetik yapıya önem verdiklerini ortaya koymuşlardır. Mckay, Buchanan, Vanderschantz, Timpany, Cunningham ve Hinze (2012) ise çalışmasında ailelerin çocuk kitaplarına ilişkin ilk izlenimi resimli öykü kitaplarının kapaklarından edindiklerini belirtmektedir. Ayrıca kitap kapaklarının ailelerin fikir yürütmelerini sağlamasının yanı sıra kitap ile ilgili çocuğun da fikir üretmesi için kullanılması gerektiğini söylemektedir. Bu bakımdan ailelerin kitap kapağından hareketle hem estetik hem de bilgi için okuma bakış açısını dikkate aldıkları söylenebilir

Ailelerin okuma öncesi beklentilerinde katılımcıların neredeyse tamamının estetik amaçlı okuma bakış açısı beklentisinde olduğu görülmektedir. Bu çalışmada yer alan okuma öncesi etkinliklere yönelik bulgulara bakıldığında ise okuma öncesi beklentilerin aksine bilgi amaçlı okuma bakış açısının merkeze alındığı görülmektedir. Bu durum ailelerin okuma öncesi beklentileri ile okuma öncesi gerçekleştirdikleri etkinlikler arasında bir tutarsızlık olduğunu göstermektedir. Ailelerin okuma sürecindeki beklentilerine ilişkin bulgulara bakıldığında ailelerin estetik amaçlı okuma bakış açısı ile bilgi için okuma bakış açısının birbirine yakın olduğu belirlenmiştir. Öte yandan okuma sürecindeki etkinliklere yönelik bulgularda, bu durumun tam aksine rastlanılmıştır. Okuma sürecinde gerçekleştirilen etkinliklere ilişkin bulguların büyük çoğunluğu, etkinliklerle bilgi amaçlı okumaya hizmet edildiğini göstermektedir. Estetik okumanın ise okuma sürecindeki etkinliklere çok düşük düzeyde yansıtıldığı belirlenmiştir. Okuma sonrası sürece ilişkin beklentilerde ise estetik amaçlı okuma 
ve bilgi için okuma bakış açısının öneminin aileler için eşit kabul edildiği tespit edilmiştir. Bu beklentilere rağmen etkinlikleri gerçekleştirirken okuma sürecinin tüm aşamalarında bilgi için okuma bakış açısı öne çıkmaktadır. Bu bulgudan hareketle ailelerin okuma süreçlerinde beklentilerinin çocuklarının estetik yönünü ve duygu dünyasını harekete geçirerek okuma sürecini daha etkin hâle getirmek olmasına rağmen bu amacı etkinliklere somut olarak yansıtamadıkları için etkinlik sürecinde estetik okumadan çok bilgi için okumanın ön plana çıktığı düşünülmektedir. Çünkü bilginin daha somut ve daha kolay ölçülebilir olduğu bilinen bir gerçektir. Bu yüzden ailelerin bilgi ve estetik amaçlı okuma bakış açısını aynı önemle okuma süreçlerine yansıtamadıkları; beklentilerin eylemlerle desteklenemediği sonucuna ulaşıımıştır. Rosenblatt'a (2005b) göre dil becerilerine ilişkin süreçlerin çoğu, bilgi için okuma ve estetik okuma bakış açısının ortasına yakın bir yerdedir; bu yüzden herhangi bir konuşma, dinleme, yazma, okuma sürecinde bu iki bakış açısının amacına uygun bir duruş benimsenmelidir. Ailelerin beklentileri ve etkinlikleri arasındaki bu tutarsızığa Okur Yanıt Teorisi açısından bakıldığında söz konusu bakış açılarının okuma süreci ile etkili bir şekilde ilişkilendirilemediği söylenebilir.

Ailelerin çocuklarına sordukları soruların hizmet ettiği bakış açısına yönelik bulgulara bakıldığında ailelerin sorduğu soruların çoğunun metin merkezli olduğu belirlenmiştir. Okur merkezli sorular ise metin merkezli sorulara göre daha az sayıdadır. Anderson-Yockel ve Haynes (1994) paylaşımlı okuma esnasında ailelerin çocuklarına sordukları sorular üzerine yürüttükleri çalışmalarında ailelerin genellikle metin merkezli sorular sorduklarını belirlemiştir. Benzer bir şekilde alanyazında Baker (2014), Pancsofar ve Vernon-Feagans (2006) da ailelerin hikaye okuma süreci sonrasında ve esnasında çocukların bilişsel özelliklerini desteklemeye yönelik sorular sorduklarını, bu soruların da genellikle metindeki bilişsel ögelerle ilişkili olduğunu (sayıları, renkler, şekiller..vb.) belirtmişlerdir. Alanyazındaki bu çalışmalar da elde edilen bulgu ile benzerlik göstermektedir. Sorularla ilgili ulaşılan bir diğer sonuç ise soruların analizinde temel alınan Wollman-Bonilla ve Werchadlo'nun (1995) analiz temalarından farklı temalara da ulaşılmış olmasıdır. Wollman-Bonilla ve Werchadlo (1995) metin merkezli, 5; okur merkezli ise 3 farklı tema sunmaktadır. Bulgularda da anlaşılacağı üzere ailelerin bu temaların hepsine hizmet eden sorular sorduğu görülmektedir. Bunların yanı sıra ailelerle yapılan görüşmelerde Wollman-Bonilla ve Werchadlo'nunkinden (1995) farklı iki temaya daha ulaşılmıştır. Bu temalar "olayı anlama" ve "resimleri yorumlama"dır. Her iki tema da metin merkezli sorular içerisinde yer almaktadır ve metin merkezli soruların neredeyse yarısını oluşturmaktadır. Bu açıdan bakıldığında ailelerin sorularını metni anlamaya yönelik farklı bakış açıları ile sordukları sonucuna ulaşılabilir. Fakat okur merkezli sorularda böyle bir duruma rastlanılmamıştır. Ailelerin sorularını sorarken hem oran açısından hem de farklı boyutları dikkate alma açısından bilgi amaçlı okuma bakış açısına daha yatkın oldukları düşünülmektedir. Soruların sorulma amacı açısından da estetik okuma bakış açısının yine bilgi amaçlı okumanın gerisinde kaldığı sonucuna ulaşımıştır.

Araştırmanın bulgularından hareketle şu önerilerde bulunulabilir:

- Okul öncesi dönemdeki çocukların ailelerinin okuma öncesi, okuma süreci ve okuma sonrası süreçlerin farklılıkları ve bu süreçlere ilişkin yapııması gerekenler konusunda farkındalıklarının artırılması gerekmektedir.

- Okul öncesi dönemdeki çocukların ailelerinin okuma sürecine yönelik bakış açıları ile ilgili farkındalıklarının artırıması gerekmektedir.

- Okul öncesi dönemdeki çocuklarda okuma sürecine geçmeden önce ailelerin beklentileri ile okuma sürecinde ailelerin çocukları ile gerçekleştirdikleri etkinliklerin amacı arasındaki tutarlıı̆ı sağlama konusunda farkındalığın artırılması gerekmektedir.

- Okul öncesi dönemdeki çocuklara yönelik soruların hizmet ettikleri amaçlar ve okuma sürecinin etkili bir şekilde gerçekleştirilebilmesi için gerekli sorular sorabilme konusunda ailelerin farkındalıklarının artırıması gerekmektedir.

\section{Kaynaklar}

Anderson-Yockel, J. ve Haynes, W (1994). Joint book reading strategies in working-class African American and white mother-toddler dyads. Journal of Speech and Hearing Research, 37, 583593. 
Aram, D. ve Shapira, R. (2012). Parent-child shared book reading and children's language, literacy, and empathy development. Rivista Italiana di Educazione Familiare, 7(2), 55-65.

Arıcı, M. ve Tüfekci Akcan, A. (2019). Okul öncesi dönemde anne-çocuk birlikte hikâye kitabı okuma davranışlarının incelenmesi. Yaşadıkça Eğitim, 33 (1), 100-120.

Baker, C.E. (2014). African American fathers' and mothers' contribution to children's early academic achievement: Evidence from two parent families from the Early Childhood Longitudinal StudyBirth Cohot. Early Childhood Education and Development, 25, 19-35.

Bamberger, R. (1990). Okuma Alışkanlığını Geliştirme (Çev: Bengü Çapar). Ankara: Kültür Bakanlı̆̆ı Yayınları.

Bayraktar, V. ve Ersoy, Ö. (2018). Çocukların devam ettikleri okul türüne göre annelerin çocuk kitapları hakkındaki görüşlerinin incelenmesi. Mersin Üniversitesi Eğitim Fakültesi Dergisi, 14 (3), 12221234.

Bıçakçı, M.Y., Er, S. ve Aral, N. (2017). Annelerin çocuklarına etkileşimli kitap okuma sürecine ilişkin görüşleri. Eğitim ve Bilim Dergisi, 42(191), 53-68. Doi:10.15390/EB.2017.7164.

Cengiz, Ş. ve Duran, E. (2017). Okul öncesi dönemine ait hikâye ve masallardaki değerlerin incelenmesi. Eğitim ve Bilim, 42 (191), 205-233.

Creswell, J. W. (2009). Research design : qualitative, quantitative, and mixed methods approaches. Thousand Oaks, Calif. : Sage Publications.

Çakmak, T. ve Yılmaz, B. (2009). Okul öncesi dönem çocuklarının okuma alışkanlığına hazırlık durumları üzerine bir araştırma: Hacettepe üniversitesi Beytepe Anaokulu örneği. Türk Kütüphaneciliği, 23 (3), 489-509.

Çocuk Vakfı Raporu (2006). Türkiye'nin okuma alışkanlığı karnesi. İstanbul: Çocuk Vakfı.

Dedeoğlu, H , Ulusoy, M . (2013). Sınıf öğretmeni adaylarının okuma tutumları / Classroom pre-service teachers' reading attitudes . Okuma Yazma Eğitimi Araştırmaları , 1 (2) , 80-88. Retrieved from https://dergipark.org.tr/en/pub/oyea/issue/20480/218129

Dedeoğlu, H. ve Kardaş, N. (2013). İlkokullarda kitap paylaşımı ve öğrencilerin okuma alışkanlıklarının geliştirilmesi. Cito Eğitim: Kuram ve Uygulama, 20, 27-36.

Dedeoğlu,H., Ulusoy, M. ve Alıcı, M. (2013). Çocuklar için hazırlanmış biyografik eserler üzerine bir içerik analizi. Hacettepe Üniversitesi Eğitim Fakültesi, 28 (2), 116-131.

Demény, P. (2012). Developing written text production competence using the reader-response method. Acta Didactica Napocensia, 5 (3), 53-60.

Demir-Lira, E., Applebaum, L.R., Goldin-Meadow, S. ve Levine, S.C. (2018). Parents' early book reading to children: Relation to children's later language and literacy outcomes controlling for other parent language input. Developmental Science, 2019, e12764. doi:10.1111/desc.12764.

Dixon- Krauss, L., Januszka, C.M. ve Chae, C. (2010). Development of the dialogic reading inventory of parent-child book reading. Journal of Research in Childhood Education 24(3), 266-277. Erişim adresi: http://dx.doi.org/10.1080/02568543.2010.487412.

Doyle, B. G., ve Bramwell, W. (2006). Promoting emergent literacy and socialemotional learning through dialogic reading. The Reading Teacher, 59(6), 554-564.

Duursma, E. (2014). Parental bookreading practices among families in the Netherlands. Journal of Early Childhood Literacy, 14(4), 435-458.

Ergül, C., Akoğlu, G., Sarıca, D., Tufan, M. ve Karaman, G. (2015). Ana sınıflarında gerçekleştirilen birlikte kitap okuma etkinliklerinin "etkileşimli kitap okuma" bağlamında incelenmesi. Mersin Üniversitesi Eğitim Fakültesi Dergisi, 11(3), 603-619. doi: 10.17860/efd.88429.

Flint, T.K. (2020). Responsive play: cerating transformative classroom spaces through play as a reader response. Journal of Early Childhood Literacy, 20 (2), 385-410.

Flint, T.K. ve Adams, M.S. (2018). "It's like playing, but learning": supporting early literacy through responsive play with wordless picturebooks. Language Arts, 96 (1), 21-36.

Glesne, C. (2013). Nitel Araştırmaya Giriş (Çev. A. Ersoy ve P. Yalçınoğlu). Ankara: Anı Yayıncılık.

Gonzalez, J. E., Taylor, A. B., Davis, M. J. ve Kim, M. (2013). Exploring the underlying factor structure of the Parent Reading Belief Inventory (PRBI): Some caveats. Early Education and Development, 24(2), 123-137. 
Gündüz, A. (2007). Anne-baba ve öğretmenlerin okul öncesi çocuk kitaplarını değerlendirmesi. Afyonkarahisar: Kocatepe Üniversitesi, Sosyal Bilimler Enstitüsü, Yayımlanmamış Yüksek Lisans Tezi.

Güner, H., Çelebi, N., Taşçı Kaya, G. ve Korumaz, M. (2014). Neoliberal eğitim politikaları ve eğitimde fırsat eşitliği bağlamında uluslararası sınavların (PISA, TIMSS ve PIRLS) analizi. Tarih Kültür ve Sanat Araştırmaları Dergisi, 3 (3), 33-75.

Hindman, A. H. , Connor, C. M., Jewkes, A. M. ve Morrison, F. J. (2008). Untangling the effects of shared book reading: Multiple factors and their associations with preschool literacy outcomes. Early Childhood Research Quarterly, 23(3), 330-350.

Hindman, A. H. , Skibbe, L. E. ve Foster, T. D. (2014). Exploring the variety of parental talk during shared book reading and its contributions to preschool language and literacy: evidence from the Early Childhood Longitudinal Study-Birth Cohort. Reading And Writing, 27(2), 287-313.

Hutton, J. S., Phelan, K., Horowitz-Kraus, T., Dudley, J., Altaye, M., DeWitt, T. ve Holland, S. K. (2017a). Story time turbocharger? Child engagement during shared reading and cerebellar activation and connectivity in preschool-age children listening to stories. PLOS ONE, 12(5), e0177398. doi: 10.1371/journal.pone.0177398.

Hutton, J. S., Phelan, K., Horowitz-Kraus, T., Dudley, J., Altaye, M., ... ve Holland, S. K. (2017b). Shared reading quality and brain activation during story listening in preschool-age children. Journal of Pediatrics, 191(December 2017), 204-212. doi: 10.1016/j.jpeds.2017.08.037.

Işıkoğlu Erdoğan, N. (2016). Erken çocukluk döneminde çocuk-ebeveyn birlikte okuma etkinliklerinin incelenmesi. Kastamonu Eğitim Dergisi, 24(3), 1071-1086.

Işıkoğlu Erdoğan, N., Şimşek, Z.C. ve Canbeldek, M. (2017). Ev merkezli diyaloğa dayalı okumanın 4-5 yaş çocuklarının dil gelişimine olan etkilerinin incelenmesi. Gazi Eğitim Fakültesi Dergisi, 37 (2), 789-809.

Kakırman Yıldız, A. (2016). Okul öncesi dönem çocuklarının okuma alışkanlığı kazanmasında rol model olarak aile. Mavi Atlas, 7, 95-112.

Kaya Tosun, D. (2018). Okuma çemberlerinin okuduğunu anlama, akıcı okuma, okuma motivasyonu ve sosyal beceriler üzerindeki etkisi ve okur yanıt tepkilerinin belirlenmesi. Denizli: Pamukkale Üniversitesi, Eğitim Bilimleri Enstitüsü, Yayınlanmamış Doktora Tezi.

Kıldan, A. O., ve Gümrükçü Bilgici, B. (2011). Okul öncesi eğitim alan çocukların ebeveynlerinin çocuk kitabı seçme ölçütlerine ilişkin görüşlerinin belirlenmesi. Milli Eğitim Dergisi, 41(192), 105-120.

Kim, J.E. ve Anderson, J. (2008). Mother-child shared reading with print and digital texts. Journal of Early Childhood Literacy, 8(2), 213-245.

Kotaman, H. (2007). Turkish parents' dialogical storybook reading experiences: A phenomenological study. Journal of Instructional Psychology, 34(4), 200-206.

Kotaman, H. (2008) Impacts of dialogical storybook reading on young children's reading attitudes and vocabulary development. Reading Improvement, 45(2), 55-61.

Levy, R. Hall, M. ve Preece, J. (2018). Examining the links between parents' relationships with reading and shared reading with their pre-school children. International Journal of Educational Psychology, 7(2), 123-150. doi:10.17583/ijep.2018.3480.

Marhaeni, A.A.I.N. (1998). Rosenblatt's transactional theory and its implementation in teaching of integrated reading. Jurnal Ilmu Pendidikan, 5 (4), 206-219.

Marjanovič-Umek, L., Hacin, K. ve Fekonja, U. (2017). The quality of mother-child shared reading: Its relations to child's storytelling and home literacy environment. Early Child Development and Care. doi: 10.1080/03004430.2017.1369975.

McKay, D., Buchanan, G., Vanderschantz, N., Timpany, C., Cunningham, S. J., ve Hinze, A. (2012, November). Judging a book by its cover: interface elements that affect reader selection of ebooks. In Proceedings of the 24th Australian Computer-Human Interaction Conference (pp. 381-390). ACM.

Merriam, S. B. (2013). Nitel Araştırma Desen ve Uygulama İçin Bir Rehber (Çev. S. Turan). Ankara: Nobel Yayıncilık. 
Miles M. ve Huberman, M. (1994). An Expanded Sourcebook Qualitative Data Analysis (2nd. Ed.). CA: Sage Publications.

Morrow, L. ve Gambrell, L. (2005). Using children's literature in preschool: Comprehending and enjoying books. Newark, DE: International Reading Association.

Özdemir, F. (2000). Kitapların dünyasında çocuk çocuğun dünyasında kitaplar. Türk Kütüphaneciliği, 14 (2), 226-232.

Öztürk Samur, A. ve Çiftçi, Y. (2019). Ailelerin nitelikli çocuk edebiyatı ürünlerini seçebilme yetkinlikleri. Iğdır Üniversitesi Sosyal Bilimler Dergisi, 18, 327-354.

Pancsofar, N. ve Vernon-Feagans, L. (2006). Mother and father language input to young children: Contributions to later language development. Journal of Applied Developmental Psychology, 27, 571-587.

Patton, M. Q. (2014). Nitel Araştırma ve Değerlendirme Yöntemleri (çev. Mesut Bütün ve Selçuk Beşir Demir). Ankara: Pegem Akademi.

Raikes, H., Pan, B.A., Luze, G., Tamis-LeMonda, C.S., Brooks-Gunn, J., ... ve Rodriguez, E.T. (2006). Mother-child bookreading in low-income families: Correlates and outcomes during the first three years of life. Child Development, 77(4), 924-953.

Rosenblatt, L. (1994). The transactional theory of reading and writing. In R. B. Rudell,M. R. Rudell, ve H. Singer (Eds.). Theoretical models and processes of reading (4thed., Vol. III, pp. 1363-1398). Newark, DE: International Reading Association.

Rosenblatt, L. M. (1938). Literature as exploration. New York: Modern Language Association of America.

Rosenblatt, L. M. (1978). The reader the text the poem: The transactional theory of the literary work. Carbondale, IL: SIU Press.

Rosenblatt, L. M. (2005a). Making meaning with texts: Selected essays. Portsmouth, NH: Heinemann.

Rosenblatt, L. M. (2005b). From "Viewpoints: Transaction versus interaction". Voices from the Middle, 12(3), 56-58

Sanacore, J. (2006). Nuturing lifetime readers. Childhood Education, 83 (1), 33-37.

Scherer, L. (2020). Where would you be in the Picture: using reader-response with children in primary school. Journal of Early Childhood Literacy, 0 (0), 1-25.

Sever, S. (2003). Çocuk ve edebiyat. (1.Baskı). Ankara: Kök Yayıncılık.

Sevim, O. (2003). Kitap okuma alışkanlığı kazandırma projesi. İstanbul: Bilge Sanat.

Shahaeian, A., Wang, C., Tucker-Drob, E., Geiger, V., Bus, A.G. ve Harrison, L.J. (2018). Early shared reading, socioeconomic status, and children's cognitive and school competencies: Six years of longitudinal evidence. Scientific Studies of Reading, 22(6), 485-502. doi: 10.1080/10888438.2018.1482901.

Sınar Çılgın, A. (2006). Çocuğa büyülü bir dünyanın kapılarını açmak. Milli eğitim Dergisi, 172, 175-182.

Sipe, L. R. (2008). Storytime: Young children's literary understanding in the classroom. NY: Teachers College Press.

Tanju, E.H. (2010). Çocuklarda kitap okuma alışkanlığına genel bir bakış. Aile ve Toplum, Nisan-MayısHaziran, 31-41.

Tercanlı Metin, G. ve Gökçay, G. (2014). Bebeklik ve erken çocukluk döneminde kitap okuma: Çocuk sağlığı izlemlerinde etkili bir gelişim önerisi. Çocuk Dergisi, 14(3), 89-94.

Tezel Şahin, F., ve Tutkun, C. (2016). Okul Öncesi Dönemde Anne, Baba, Çocuk ve Kitap. Kastamonu Education Journal, 24(5), 2373- 2390.

Tipton, L. A. (2014). The parent's role: Shared book reading and the child with asd. Riverside: University of California, Yayımlanmamış Doktora Tezi.

Vandermaas-Peeler, M., Sassine, B., Price, C. ve Brilhart, C. (2011). Mothers 'and fathers' guidance behaviours during storybook reading. Journal of Early Childhood Literacy, 12(4), 415-442.

Whitehurst, G. T. ve Lonigan, C. J. (1998). Child development and emergent literacy. Child Development, 69(3), 848-872.

Wollman-Bonilla, J., \& Werchadlo, B. (1995). Literature response journals in a first-grade classroom. Language Arts, 72, 562-570. 
Wuryaningrum, R., Suyitno, I., Suyono, S., \& Sunaryo, S. (2017). Efferent-Aesthetic Reading in Reading across Curricula (An Implementation at Living Environment Education in Islamic Elementary School As-Salam, Malang, Indonesia). The International Journal of Social Sciences and Humanities Invention, 4(9), 3975-3982.

Yin, R. K. (2009). Case study research: Design and methods (4th ed.). Thousand Oaks, CA: Sage.

Yurtseven, L. (2011). Annelerin çocuklarına hikâye okumasının çocukların sosyal beceri gelişimine etkisinin incelenmesi. Malatya: İnönü Üniversitesi, Eğitim Bilimleri Enstitüsü, Yayımlanmamış Yüksek Lisans Tezi.

\section{Introduction}

\section{Extended Abstract}

There are many studies in the literature on reading processes in the preschool period. It has been determined that these studies are mostly related to interactive reading, dialogue-based reading, and shared reading. It is seen that most of the studies (Ergül, Akoğlu, Sarıca, Tufan ve Karaman, 2015; Hindman, Connor, Jewkes ve Morrison, 2008; Hutton ve diğerleri, 2017a, 2017b; Kotaman, 2008; Morrow ve Gambrell, 2005; Shahaeian ve diğerleri, 2018; Tercanlı Metin ve Gökçay, 2014; Whitehurst ve Lonigan, 1998) focus on the reading processes of preschool teachers. However, it is observed that there are also studies on reading processes in their families with their children (Aram and Shapira, 2012; Bıçakçı, Er and Aral, 2017; Demir-Lira, Applebaum, Goldin-Meadow and Levine, 2018; DixonKrauss, Januszka and Chae, 2010; Gonzalez, Taylor, Davis and Kim, 2013; Hindman, Skibbe and Foster, 2014; Işıkoğlu Erdoğan, 2016; Kim and Anderson, 2008; Kotaman, 2007; Levy, Hall and Preece, 2018; Marjanovič-Umek, Hacin and Fekonja, 2017; Raikes and diğerleri, 2006; Tipton, 2014; VandermaasPeeler, Sassine, Price and Brilhart, 2011; Yurtseven, 2011). On the other hand, there wasn't found study to determine the expectations of families about their children's reading processes in the preschool period. In this context, it is thought that this study, which aims to determine the expectations of their families from the reading processes of preschool children at home with their families, will make significant contributions to both the national literature and the international literature. When the national literature is examined, it has been determined that there are almost no studies in the preschool field where Reader Response Theory is used (Dedeoğlu and Kardaş, 2013; Dedeoğlu and Ulusoy, 2013; Dedeoğlu, Ulusoy and Alı, 2013). It can be said that it is an important study in terms of the implementation of the application and revealing the expectations of families from children's reading processes. In this study, it is aimed to examine the reading processes of preschool children with their families at home in the context of Reader Response Theory according to the expectations of the families.

\section{Method}

This study, which was carried out with the qualitative research method, was designed by case study. The main reason for choosing a case study for this study is that it is a design that takes a holistic view of a certain situation (Creswell, 2009; Glesne, 2013; Merriam, 2013). Because in this study, the reading processes of preschool children with their families at home were examined based on the parents' stance. In particular, the expectations of families in the reading processes of preschool children at home were tried to be put forward with a holistic stance. In this study conducted with the families of preschool children, the holistic single case design was used. The reason why the holistic single-case pattern was preferred in this study is that it is based on the Reader Response Theory developed by Louise Rosenblatt, which is a framework for reading education and the expectations of families regarding the children's reading process. The participants of the study consists of parents of children in preschool selected from one of Turkey's north-west of the city. As in all researches, economy is important in qualitative research in every aspect. In this respect, easily accessible situation sampling was used. The participants of the study consist of 54 ( 8 men, 46 women) people. The ages of the families range from 21 to 48 years old. Most of these participants from different professions have only 1 child in the preschool period. Semi-structured interview form, which is one of the qualitative research techniques, was used in this study designed with qualitative research method. In the study 
conducted with the families of preschool children, two different semi-structured interview forms were developed to determine the expectations and stances of the families. The data of the study are arranged in a way to serve research questions. Data on each research question were analyzed differently. Data for the first and second research questions were analyzed with content analysis technique; the data for the third research question were analyzed with the descriptive analysis technique.

\section{Result and Discussion}

This study was carried out to examine the reading processes of preschool children with their families at home, according to the expectations of the families. During home reading processes, the books chosen by families for their children, reading process expectations, reading activities and asking questions were evaluated in terms of the Reader-Response Theory. There is no study in the literature on determining the expectations of families about their children's reading processes in the preschool period. When the national literature is examined, it has been determined that there are almost no studies in the preschool field where Reader Response Theory is used (Dedeoğlu and Kardaş, 2013; Dedeoğlu and Ulusoy, 2013; Dedeoğlu, Ulusoy and Alıcl, 2013). For this reason, it is thought that this study serves a different purpose than other studies in the literature in terms of both the application of Reader Response Theory in the preschool field and determining the expectations of families regarding reading processes.

Based on the findings about what families pay attention to when choosing books for their children, it has been determined that the most important criterion is to address the interests of the children. It is seen that most of the participants chose a book for efferent reading stance. From this point of view, it has been concluded that families attach more importance to efferent reading stance than aesthetic reading stance while choosing books.

It is seen that almost all of the participants expect a reading stance for aesthetic purposes in families' pre-reading expectations. Considering the findings regarding pre-reading activities, it is seen that, contrary to pre-reading expectations, the efferent reading stance is taken into the center. Considering the findings regarding the expectations of families in the reading process, it was determined that the families' stance of aesthetic reading and efferent reading are close to each other. On the other hand, in the findings regarding the activities in the reading process, the exact opposite was encountered. The majority of the findings regarding the activities carried out in the reading process show that the activities serve for efferent reading. In the expectations regarding the postreading process, it was determined that the importance of aesthetic reading and efferent reading is considered equal for families. Despite these expectations, the efferent reading stance comes to the fore at all stages of the reading process while performing the activities. 